\title{
Pengaruh Sistem Informasi Akuntansi, Pengembangan Sumber Daya Manusia Terhadap Pengendalian Intern dan Laporan Keuangan yang Handal
}

\author{
Denny Mahendra ${ }^{1)}$, Jarot Santosa ${ }^{2)}$, Aris Tri Haryanto ${ }^{3)}$ \\ ${ }^{1,2,3}$ Sekolah Tinggi Ilmu Ekonomi AUB Surakarta \\ *Email korespondensi: dennymahendr@gmail.com
}

\begin{abstract}
The Boyolali District Government succeeded in obtaining a Fair Opinion without Exception (WTP) opinion from the Financial Supervisory Agency after conducting an audit of the Boyolali Regency's financial statements in 2016. The Accounting Information System and Human Resource Development System had a significant effect on Internal Control. Accounting Information Systems, Human Resource Development and Internal Control have a significant effect on Reliable Financial Statements. The population of this study is the Regional Work Unit (SKPD) which is responsible for making financial reports in Boyolali Regency, as many as 75 employees. The sampling technique in this study is the census. The results showed that the Accounting Information System has a significant effect on internal control. Human resource development has a significant effect on internal control. Accounting Information Systems have a significant effect on reliable financial statements. Human resource development has a significant effect on reliable financial statements. Internal control has a significant effect on Reliable Financial Statements. The results of the path analysis are known to track the development of human resources on reliable financial statements, which is the dominant or effective path to improving reliable financial statements.
\end{abstract}

Keywords : Accounting Information Systems, human resource development, internal control, Reliable Financial Statements

Saran sitasi: Mahendra, D., Santosa, J., \& Haryanto, A. T. (2020). Pengaruh Sistem Informasi Akuntansi, Pengembangan Sumber Daya Manusia Terhadap Pengendalian Intern dan Laporan Keuangan yang Handal. Jurnal Akuntansi dan Pajak, 21 (1), 32-39. doi:http://dx.doi.org/10.29040/jap.v21i1.1007

DOI: http://dx.doi.org/10.29040/jap.v21i1.1007

\section{PENDAHULUAN}

Era globalisasi ini, organisasi dituntut untuk terus mempersiapkan dirinya mengantisipasi dan menyesuaikan diri dengan perubahan. Pengalaman yang dialami berbagai di negara maju menunjukkan bahwa hanya organisasi yang secara konsisten terus meningkatnya dirinya melalui perkembangan organisasi yang dapat bertahan (Rahayu, 2016:65). Seorang profesional pun dituntut harus bisa mengembangkan keahlian dibidang komputer. Dengan program akuntansi, semua aspek bisnis yang dikelola dapat diukur dengan tepat waktu tanpa harus menunggu laporan keuangan yang dibuat secara manual dan memakan waktu yang lama.Informasi akuntansi sangat penting bagi perusahaan yang digunakan untuk perencanaan, pengendalian, serta pengambilan keputusan yang efektif.

Hasil penelitian yang dilakukan Tuti Herawati (2014:98) yang menyatakan bahwa pengaruh sistem pengendalian intern berpengaruh positif dan signifikan terhadap kualitas laporan keuangan pemerintah daerah, sedangkan penelitian Kiranayanti dan Erawati (2016:76) hasil penelitian ini menunjukkan bahwa sistem pengendalian intern berpengaruh tidak signifikan terhadap kualitas laporan keuangan pemerintah daerah, sehingga dengan adanya research gap tersebut, perlu dilakukan pembuktian secara empiris. Keterandalan adalah kemampuan informasi guna meyakinkan bahwa informasi tersebut benar dan valid. Berdasarkan PP No 71 Tahun 2015, Laporan 


\section{Jurnal Akuntansi dan Pajak, 21 (01), 2020, 33}

Keuangan yang Handal merupakan informasi dalam laporan keuangan bebas dari pengertian yang menyesatkan dan kesalahan material, menyajikan setiap fakta secara jujur, serta dapat diverifikasi. Infomasi mungkin relevan, apabila hakikat atau penyajiannya tidak dapat diandalkan maka penggunaan informasi tersebut secara potensial dapat menyesatkan. Pelaporan merupakan sarana untuk perusahaan yang digunakan untuk menyampaikan suatu informasi dan pengukuran secara ekonomi tentang sumber daya yang dimiliki dan kinerjanya pada berbagai pihak yang memiliki kepentingan atas informasi tersebut.

Sistem informasi akuntansi adalah komponen penting yang dapat memenuhi kebutuhan yang tepat dan akurat.Sistem informasi akutansi terkomputerisasi juga mempunyai peranan penting dalam sebuah organisasi dan semakin berkembangnya dalam suatu organisasi menyebabkan transaksi menjadi semakin banyak dan kompleks.Perkembangan teknologi dan kemajuan jaman serta semakin banyaknya organisasi bisnis maupun organisasi sektor publik seperti di Pemerintah Daerah yang terus berkembang. Satuan Kerja Perangkat Daerah (SKPD) berusaha meningkatkan kualitas sumber daya manusia yang diharapkan dapat meningkatkan kinerja dalam organisasi tersebut. Mengetahui apa yang menjadi kebutuhan sistem informasi bagian keuangan dan sekaligus dapat menjadi masukan terhadap bagian yang mengelola sistem informasi dalam mengembangkan sistem yang sudah ada. Hasil yang optimal akan dihadapkan dalam permasalahan yang berhubungan dengan keterandalan pelaporan dalam laporan keuangan. Jadi, sistem informasi sangat penting karena dengan sistem informasi akuntansi yang baik maka kinerja yang dimiliki juga akan berkualitas, efektif dan relevan.

Teknologi yang berkembang terutama di era reformasi sangat berdampak signifikan terhadap Sistem Informasi Akuntansi dalam suatu organisasi di pemerintah daerah seperti SKPD. Dampak yang diwujudkan secara nyata adalah pemrosesan data yang mengalami perubahan dari sistem manual ke sistem komputerisasi dan bermunculnya softwaresoftware untuk akuntansi mempermudah dalam membuat laporan keuangan.Sistem informasi memberikan manfaat ketepatan pelaporan keuangan sesuai dengan waktu yang sudah ditetapkan serta mempermudah pemrosesan data dalam pembuatan laporan keuangan. Sumber daya manusia merupakan salah satu faktor penting dalam pembangunan dari sebuah organisasi.Pengembangan sumber daya manusia dalam suatu oraganisasi adalah upaya untuk meningkatkan kemampuan pegawai yang dalam penelitian ini dilakukan melalui pendidikan dan pelatihan dalam rangka untuk mencapai tujuan organisasi secara efektif dan efisien. Sumber daya manusia yang mengelola keuangan seharusnya dalam melaksanakan proses akuntansi seharusnya mengikuti peraturan yang sudah ditetapkan untuk menciptakan sumber daya manusia yang handal membutuhkan pengelolaan yang baik agar sumber daya manusia lebih optimal. Pengembangan sumber daya manusia menjadikan para pegawai lebih berkompeten sesuai standar yang dibuat oleh organisasi sehingga mempengaruhi keterandalan dalam pembuatan laporan keuangan yang bermanfaat dan bernilai

Pengendalian intern adalah suatu rancangan prosedur organisasi yang mendorong terciptanya kebijakan manajemen untuk menciptakan efisiensi operasional, melindungi aktiva, serta mencegah penyelewengan aktiva perusahaan atau organisasi.Sistem pengendalian merupakan bagian yang tidak terpisahkan dari sistem informasi akuntansi. Tanpa dukungan sistem pengendalian intern yang memadai sistem informasi tidak akan dapat menghasilkan informasi yang handal dalam pengambilan keputusan. sistem pengendalian intern ini juga digunakan untuk mengecek kesalahankesalahan yang terjadi sehingga dapat dikoreksi. Pengendalian intern disusun guna untuk memberikan kepastian yang layak mengenai penerapan tujuan dalam pelaporan keuangan, kepatuhan terhadap hukum peraturan yang berlaku serta efektivitas dan efisiensi operasi (Arens, 2016:76).

Pemerintah Kabupaten Boyolali berhasil meraih opini Wajar Tanpa Pengecualian (WTP) dari Badan Pengawasan Keuangan setelah melakukan audit atas laporan keuangan pemerintah daerah (LKPD) Kabupaten Boyolali tahun 2016. Namun opini wajar tanpa pengecualian yang diberikan Badan Pengawasan Keuangan terhadap laporan keuangan 


\section{Jurnal Akuntansi dan Pajak, 21 (01), 2020, 34}

pemerintah Kabupaten Boyolali bukan berarti bebas dari kesalahan dan kelemahan. BPK RI menemukan permasalahan yakni masih rendahnya kualitas informasi laporan keuangan daerah yang disebabkan oleh pemahaman akuntansi dari penyusunan laporan itu sendiri yang berhubungan langsung dengan pengembangan sumber daya manusia, belum diterapkannya secara optimal sistem akuntansi keuangan dan masih lemahnya sistem pengendalian intern.

Berdasarkan latar belakang maka penulis tertarik untuk melakukan penelitian yang berjudul "Pengaruh Sistem Informasi Akuntansi, Pengembangan Sumber Daya Manusia, Pengendalian Intern Terhadap Laporan Keuangan yang Handal (Studi Kasus Pada Satuan Kerja Pemerintah Daerah Kabupaten Boyolali)".

\section{METODE PENELITIAN}

Lokasi penulisan ini adalah Lingkup Kantor Dinas Kabupaten Boyolali, dan obyek penelitian ini adalah seluruh pegawai bagian akuntansi pada Lingkup Kantor Dinas Kabupaten Boyolali. Populasi dari penelitian ini adalah Satuan Kerja Perangkat Daerah (SKPD) yang bertanggung jawab dalam pembuatan laporan Keuangan di Kabupaten Boyolali yaitu sebanyak 75 pegawai. Teknik pengambilan sampel dalam penelitian ini adalah sensus, yaitu seluruh anggota populasi dijadikan sebagai sampel. Sehingga sampel yang diambil dalam penelitian ini adalah seluruh anggota populasi dijadikan sampel yaitu sebanyak 75 responden pegawai yang bertanggung jawab untuk pembuatan laporan keuangan di Kabupaten Boyolali. Teknik analisis menggunakan analisi jalur yang digunakan untuk mengatahui pengaruh langsung maupun pengaruh tidak langsung. Untuk menguji hipotesis menggunakan analisis regresi linier berganda.

\section{HASIL DAN PEMBAHASAN}

\subsection{Hasil penelitian}

Tabel.1. Rincian Jumlah Responden pada setiap SKPD

\begin{tabular}{ccc}
\hline NO. Nama Satuan Kerja Perangkat & Kuesioner \\
Daerah (SKPD) & $\begin{array}{c}\text { yang } \\
\text { dapat } \\
\text { digunakan }\end{array}$ \\
& & \\
&
\end{tabular}

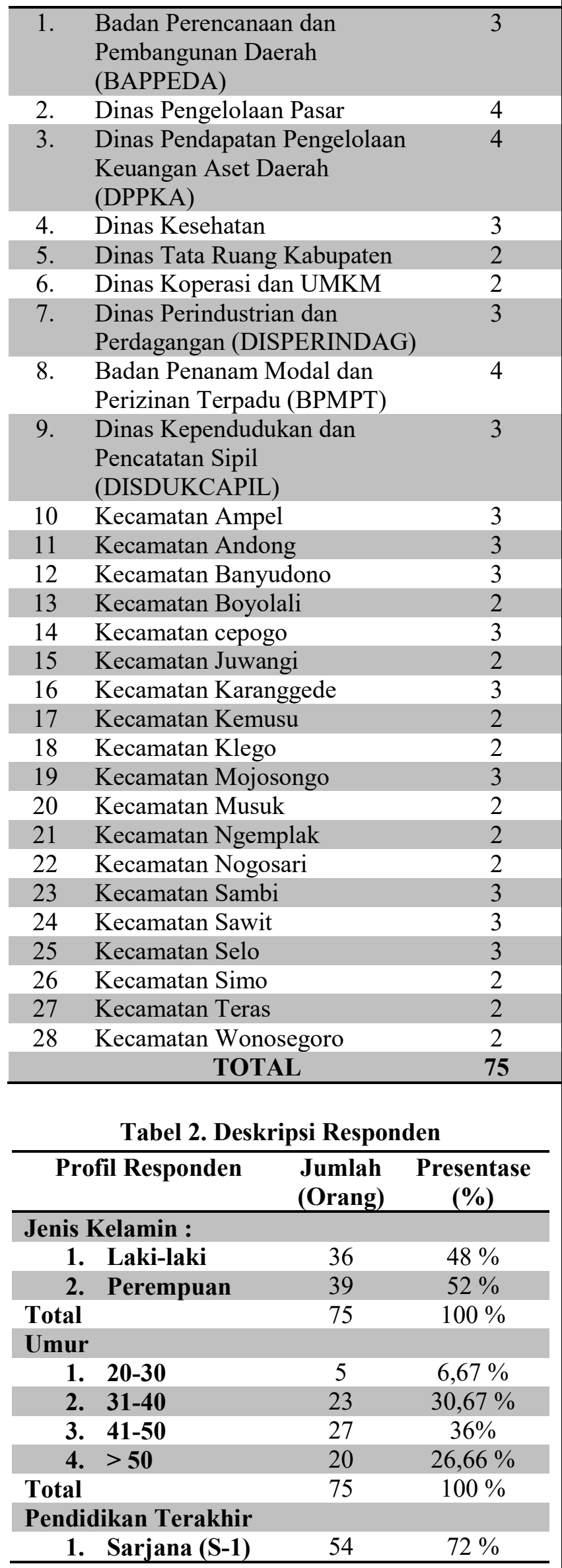




\begin{tabular}{|c|c|c|c|}
\hline \multicolumn{4}{|c|}{ Jurnal Akuntansi dai } \\
\hline \multicolumn{2}{|c|}{ 2. Sarjana (S-2) } & 21 & $28 \%$ \\
\hline \multicolumn{2}{|c|}{ Total } & 75 & $100 \%$ \\
\hline \multicolumn{4}{|c|}{$\begin{array}{c}\text { Tabel 3. Uji Validitas Variabel Sistem Informasi } \\
\text { Akuntansi }\end{array}$} \\
\hline $\begin{array}{c}\text { Item } \\
\text { Pertanyaan }\end{array}$ & $\mathbf{r}_{\text {item }}$ & $\mathbf{r}_{\text {tabel }}$ & Ketarangan \\
\hline $\mathrm{X} 1 \_1$ & 0,700 & 0,244 & Valid \\
\hline $\mathrm{X} 1 \_2$ & 0,596 & 0,244 & Valid \\
\hline X1_3 & 0,707 & 0,244 & Valid \\
\hline X1_4 & 0,413 & 0,244 & Valid \\
\hline X1_5 & 0,617 & 0,244 & Valid \\
\hline
\end{tabular}

Sumber : Data yang diolah, 2020

Tabel 4. Uji Validitas Variabel Pengembangan sumber daya manusia

\begin{tabular}{|c|c|c|c|}
\hline $\begin{array}{c}\text { Item } \\
\text { Pertanyaan }\end{array}$ & $\mathbf{r}_{\text {item }}$ & $\mathbf{r}_{\text {tabel }}$ & Ketarangan \\
\hline $\mathrm{X} 2 \_1$ & 0,751 & 0,244 & Valid \\
\hline $\mathrm{X} 2 \_2$ & 0,769 & 0,244 & Valid \\
\hline $\mathrm{X} 2 \_3$ & 0,795 & 0,244 & Valid \\
\hline $\mathrm{X} 2 \_4$ & 0,662 & 0,244 & Valid \\
\hline $\mathrm{X} 2 \_5$ & 0,565 & 0,244 & Valid \\
\hline
\end{tabular}

Sumber : Data yang diolah, 2020

Tabel 5. Uji Validitas Variabel Pengendalian intern

\begin{tabular}{|c|c|c|c|}
\hline $\begin{array}{c}\text { Item } \\
\text { Pertanyaan }\end{array}$ & $\mathbf{r}_{\text {item }}$ & $\mathbf{r}_{\text {tabel }}$ & Ketarangan \\
\hline X3_1 & 0,851 & 0,244 & Valid \\
\hline X3_2 & 0,800 & 0,244 & Valid \\
\hline X3_3 & 0,829 & 0,244 & Valid \\
\hline X3_4 & 0,759 & 0,244 & Valid \\
\hline X3_5 & 0,726 & 0,244 & Valid \\
\hline
\end{tabular}

Sumber : Data yang diolah, 2020

Tabel 6. Uji Validitas Variabel Laporan Keuangan yang Handal

\begin{tabular}{|c|c|c|c|}
\hline $\begin{array}{c}\text { Item } \\
\text { Pertanyaan }\end{array}$ & $\mathbf{r}_{\text {item }}$ & $\mathbf{r}_{\text {tabel }}$ & Ketarangan \\
\hline Y_1 & 0,774 & 0,244 & Valid \\
\hline Y_2 & 0,822 & 0,244 & Valid \\
\hline Y_3 & 0,811 & 0,244 & Valid \\
\hline Y_4 & 0,781 & 0,244 & Valid \\
\hline
\end{tabular}

\begin{tabular}{|c|c|c|c|}
\hline Y_5 & 0,779 & 0,244 & Valid \\
\hline Y_6 & 0,465 & 0,244 & Valid \\
\hline
\end{tabular}

Sumber : Data yang diolah, 2020

Tabel 7. Hasil Uji Reliabilitas

\begin{tabular}{|c|c|c|c|}
\hline Variabel & $\begin{array}{l}\text { Nilai } \\
\text { AC }\end{array}$ & Kriteria & Ket. \\
\hline SIA & 0,797 & Alpha & Reliabel \\
\hline Pengembangan & 0,875 & Cronbach & Reliabel \\
\hline SDM & & $>0,60$ & Reliabel \\
\hline Pengendalian intern & 0,914 & maka & Reliabel \\
\hline $\begin{array}{l}\text { Laporan Keuangan } \\
\text { yang Handal }\end{array}$ & 0,898 & reliabel & \\
\hline
\end{tabular}

Sumber : Data yang diolah, 2020

Tabel 8. Hasil Analisis Jalur Persamaan 1

\begin{tabular}{|c|c|c|c|c|c|c|}
\hline \multirow[b]{2}{*}{ Model } & & \multicolumn{2}{|c|}{ Unstandardized Coefficients } & \multirow{2}{*}{$\begin{array}{c}\text { Standardized } \\
\text { Coefficients } \\
\text { Beta }\end{array}$} & \multirow[b]{2}{*}{$t$} & \multirow[b]{2}{*}{ Sig. } \\
\hline & & B & Std. Error & & & \\
\hline 1 & (Constant) & -250 & 1.435 & & -.174 & .862 \\
\hline & $\begin{array}{l}\text { Sistem_Informasi_Akunta } \\
\text { nsi }\end{array}$ & .485 & .072 & .522 & 6.751 & .000 \\
\hline & Pengembangan_SDM & .500 & .089 & .432 & 5.587 & .000 \\
\hline
\end{tabular}

DependentVariable: Pengendalian_Intern

Sumber : Data yang diolah, 2020

Keterangan:

$$
Y_{1}=0,522 X_{1}+0,432 X_{2}+\epsilon_{1}
$$

Dari hasil di atas maka dapat dijelaskan sebagai berikut:

1) $\beta_{1}=$ koefisien regresi variabel Sistem Informasi Akuntansi sebesar 0,522 hal ini menunjukkan bahwa variabel Sistem Informasi Akuntansi berpengaruh positif terhadap pengendalian intern pegawai di Satuan Kerja Pemerintah Daerah Kabupaten Boyolali.

2) $\beta_{2}=$ koefisien regresi variabel pengembangan sumber daya manusia sebesar 0,432 hal ini menunjukkan bahwa variabel pengembangan sumber daya manusia berpengaruh positif terhadap pengendalian intern Pegawai di Satuan Kerja Pemerintah Daerah Kabupaten Boyolali.

Tabel 9. Hasil Analisis Jalur Persamaan 2

\begin{tabular}{|c|c|c|c|c|c|c|}
\hline \multirow[b]{2}{*}{ Model } & & \multicolumn{2}{|c|}{ Unstandardized Coefficients } & \multirow{2}{*}{$\begin{array}{c}\text { Standardized } \\
\text { Coefficients } \\
\text { Beta }\end{array}$} & \multirow[b]{2}{*}{$t$} & \multirow[b]{2}{*}{ Sig. } \\
\hline & & B & Std. Error & & & \\
\hline \multirow[t]{3}{*}{1} & (Constant) & 4.565 & .933 & & 4.895 & .000 \\
\hline & $\begin{array}{l}\text { Sistem_Informasi_Akunta } \\
\mathrm{nsi}\end{array}$ & .291 & .060 & .336 & 4.870 & .000 \\
\hline & Pengembangan_SDM & .472 & .070 & .438 & 6.780 & .000 \\
\hline & Pengendalian_Intern & .241 & .077 & .259 & 3.152 & .002 \\
\hline
\end{tabular}




\section{Jurnal Akuntansi dan Pajak, 21 (01), 2020, 36}

Sumber : Data yang diolah, 2020

$$
Y_{2}=0,336 X_{1}+0,438 X_{2}+0,259 X_{3}+c_{2}
$$

Dari hasil diatas maka dapat dijelaskan sebagai berikut:

1. $\beta_{1}=$ koefisien regresi variabel Sistem Informasi Akuntansi sebesar 0,336 hal ini menunjukkan bahwa variabel Sistem Informasi Akuntansi berpengaruh positif terhadap Laporan Keuangan yang Handal pegawai di Satuan Kerja Pemerintah Daerah Kabupaten Boyolali, apabila Sistem Informasi Akuntansi ditingkatkan maka Laporan Keuangan yang Handal Pegawai di Satuan Kerja Pemerintah Daerah Kabupaten Boyolali akan meningkat.

2. $\beta_{2}=$ koefisien regresi variabel pengembangan sumber daya manusia sebesar 0,438 hal ini menunjukkan bahwa variabel pengembangan sumber daya manusia berpengaruh positif terhadap Laporan Keuangan yang Handal Pegawai di Satuan Kerja Pemerintah Daerah Kabupaten Boyolali, hal ini berarti apabila pengembangan sumber daya manusia ditingkatkan maka Laporan Keuangan yang Handal Pegawai di Satuan Kerja Pemerintah Daerah Kabupaten Boyolali akan meningkat.

3. $\beta_{3}=$ koefisien regresi variabel pengendalian intern sebesar 0,259 hal ini menunjukkan bahwa variabel pengendalian intern berpengaruh positif terhadap Laporan Keuangan yang Handal Pegawai di Satuan Kerja Pemerintah Daerah Kabupaten Boyolali, hal ini berarti apabila pengendalian intern ditingkatkan maka Laporan Keuangan yang Handal Pegawai di Satuan Kerja Pemerintah Daerah Kabupaten Boyolali akan meningkat.

Tabel 10. Hasil Uji F

\begin{tabular}{|c|c|c|c|c|c|c|}
\hline \multicolumn{2}{|c|}{ Model } & $\begin{array}{l}\text { Sum of } \\
\text { Squares }\end{array}$ & $\mathrm{df}$ & Mean Square & $F$ & Sig. \\
\hline \multirow[t]{3}{*}{1} & Regression & 390.950 & 3 & 130.317 & 182.866 & b \\
\hline & Residual & 50.597 & 71 & .713 & & \\
\hline & Total & 441.547 & 74 & & & \\
\hline
\end{tabular}

Dependent Variable: Laporan_Keuangan_Yang_Handal

Predictors: (Constant), Pengendalian_Intern, Pengembangan_SDM, Sistem_Informasi_Akuntansi

Sumber : Data yang diolah, 2020

\section{Koefisien Determinasi / Varian Total}

$$
\begin{aligned}
\mathrm{R}^{2} \text { total }= & 1-\left\{\left(\epsilon_{1}\right)^{2} x\left(\epsilon_{2}\right)^{2}\right\}=1-\left\{(0,488)^{2} \mathrm{x}\right. \\
& \left.(0,339)^{2}\right\}=1-\{(0,239) \times(0,115)\}=1 \\
& -0,027=0,973
\end{aligned}
$$

Nilai $\mathrm{R}^{2}$ total sebesar 0,973 dapat diartikan variasi Laporan Keuangan yang Handal Pegawai di Satuan Kerja Pemerintah Daerah Kabupaten Boyolali dijelaskan oleh variabel Sistem Informasi Akuntansi, pengembangan sumber daya manusia dan pengendalian intern, sebesar $97,3 \%$ dan sisanya $2,7 \%$ dijelaskan variabel lain diluar model penelitian

\begin{tabular}{|c|c|c|c|}
\hline \multirow[b]{2}{*}{$\begin{array}{c}\text { Dari } \\
\text { Variabel }\end{array}$} & \multicolumn{2}{|c|}{ Koefisien Jalur } & \multirow[b]{2}{*}{$\begin{array}{c}\text { Total } \\
\text { Pengaruh }\end{array}$} \\
\hline & $\begin{array}{c}\mathrm{DE} \\
(\text { Direct } \\
\text { Effect })\end{array}$ & $\begin{array}{c}\mathrm{IE} \\
\text { (Indirect } \\
\text { Effect) }\end{array}$ & \\
\hline $\mathrm{X}_{1}$ ke $\mathrm{Y}$ & $\mathrm{P}_{3}=0,336$ & & \\
\hline $\mathrm{X}_{2}$ ke $\mathrm{Y}$ & $\mathrm{P}_{4}=0,438$ & & \\
\hline $\begin{array}{c}\mathrm{X}_{1} \\
\text { melalui } \\
\mathrm{X}_{3} \text { Ke Y }\end{array}$ & & $\begin{array}{l}=P_{1} \times P_{5} \\
=0,522 \times \\
0,259= \\
0,135\end{array}$ & $\begin{array}{l}=\mathrm{P}_{3}+ \\
\left(\mathrm{P}_{1} \mathrm{xP}_{5}\right) \\
=0,336+ \\
0,135= \\
0,471\end{array}$ \\
\hline $\begin{array}{c}\mathrm{X}_{2} \\
\text { melalui } \\
\mathrm{X}_{3} \text { Ke Y }\end{array}$ & & $\begin{array}{l}=P_{2} \times P_{5} \\
=0,432 \times \\
0,259= \\
0,112\end{array}$ & $\begin{array}{l}=P_{4}+\left(P_{2} \mathrm{X}\right. \\
\left.P_{5}\right) \\
=0,438+ \\
0,112= \\
0,55\end{array}$ \\
\hline
\end{tabular}
sebagai contoh iklim organisasi dan pengalaman pegawai.

Tabel 11. Hasil Analisis Jalur

Sumber: Data diolah 2020

Gambar 1. Hasil Model Analisis Jalur 


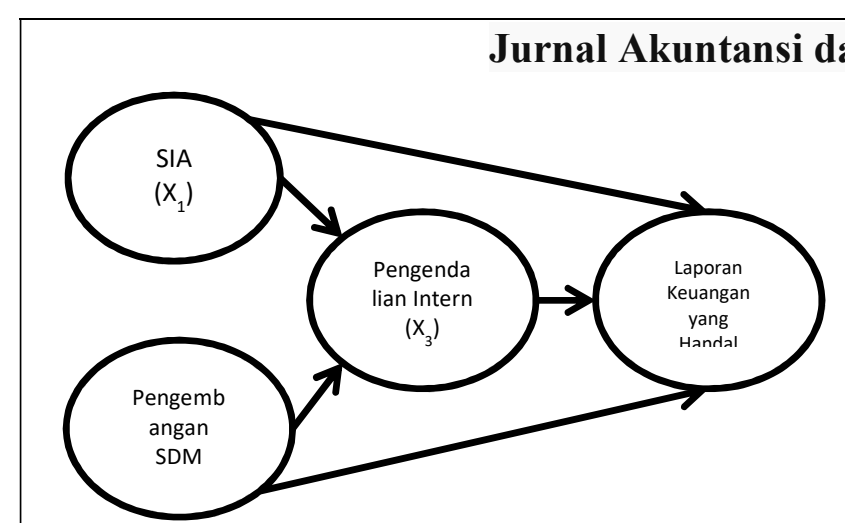

Sumber: Data diolah 2020

\subsection{Pembahasan}

\section{Pengaruh Sistem Informasi Akuntansi dengan Laporan Keuangan yang Handal melalu pengendalian intern}

Berdasarkan hasil analisis jalur, pengaruh langsung Sistem Informasi Akuntansi signifikan terhadap Laporan Keuangan yang Handal pegawai di Satuan Kerja Pemerintah Daerah Kabupaten Boyolali, artinya apabila semakin tinggi Sistem Informasi Akuntansi, maka semakin tinggi Laporan Keuangan yang Handal pegawai di Satuan Kerja Pemerintah Daerah Kabupaten Boyolali.

Hasil penelitian yang dilakukan oleh Haryadi Sarjono Lim Sanny, Sheftian Pancha Cahyo (2013), Wati (2012), Nurul Faridilla (2010) menemukan hasil dalam penelitiannya bahwa Sistem Informasi Akuntansi berpengaruh signifikan terhadap Laporan Keuangan yang Handal. Hasil penelitian yang dilakukan oleh Karyanto (2014), Joko Istiyanto (2014), Slamet Widodo (2014), menemukan hasil dalam penelitiannya bahwa Sistem Informasi Akuntansi berpengaruh tidak signifikan terhadap Laporan Keuangan yang Handal.

Pengaruh tidak langsung diperoleh temuan bahwa Sistem Informasi Akuntansi signifikan terhadap pengendalian intern dan pengendalian intern signifikan terhadap Laporan Keuangan yang Handal. Sistem Informasi Akuntansi signifikan terhadap pengendalian intern. Hasil ini mendukung atau tidak mendukung penelitian yang dilakukan oleh Karyanto (2014), Joko Istiyanto (2014), Haryadi Sarjono Lim Sanny, Wati (2012), hasil dalam penelitiannya bahwa Sistem Informasi Akuntansi berpengaruh signifikan terhadap pengendalian intern.

Pengendalian intern signifikan terhadap Laporan Keuangan yang Handal. Hasil penelitian ini mendukung hasil penelitian yang dilakukan oleh I Wayan Mudiartha Utama (2012), Rahmila Sari (2011), hasil penelitiannya menunjukkan bahwa pengendalian intern berpengaruh signifikan terhadap Laporan Keuangan yang Handal. Hasil penelitian ini mendukung hasil penelitian yang dilakukan oleh Stephanie Tanto Kurniawan, Faustine (2014), hasil penelitiannya menunjukkan bahwa pengendalian intern berpengaruh tidak signifikan terhadap Laporan Keuangan yang Handal.

Hasil koefisien nilai pengaruh langsung Sistem Informasi Akuntansi signifikan terhadap Laporan Keuangan yang Handal lebih besar dibandingkan pengaruh tidak langsung, Sistem Informasi Akuntansi melalui pengendalian intern terhadap Laporan Keuangan yang Handal maka analisis jalur yang digunakan efektif melalui pengaruh langsung.

Sehingga upaya untuk meningkatkan Laporan Keuangan yang Handal dalam menggunakan pengaruh langsung yaitu peningkatan perilaku Sistem Informasi Akuntansi untuk meningkatkan perilaku Laporan Keuangan yang Handal. Peningkatan perilaku Sistem Informasi Akuntansi untuk meningkatkan perilaku Laporan Keuangan yang Handal secara kongkrit dilakukan dengan melihat skor uji validitas Sistem Informasi Akuntansi pada item pertanyaan tertinggi, yaitu: Penggunaan sistem informasi mampu membantu proses administrasi secara relevan dalam pelaporan laporan keuangan, sehingga dapat mengevaluasi kinerja. SIA mempermudah pelaporan keuangan. Penggunaan sistem informasi mampu membantu proses administrasi secara tepat waktu dalam pelaporan laporan keuangan, sehingga SIA dapat mengevaluasi kinerja.

\section{Pengaruh Pengembangan sumber daya manusia dengan Laporan Keuangan yang Handal melalui pengendalian intern}

Berdasarkan analisis jalur bahwa jalur diketahui pengaruh pengembangan sumber daya manusia terhadap Laporan Keuangan yang Handal signifikan, artinya semakin tinggi tingkat pengembangan sumber daya manusia, semakin tinggi Laporan Keuangan yang Handal yang dihasilkan oleh pegawai Satuan Kerja Pemerintah Daerah Kabupaten Boyolali. 


\section{Jurnal Akuntansi dan Pajak, 21 (01), 2020, 38}

Temuan ini mendukung hasil penelitian yang dilakukan oleh I Wayan Mudiartha Utama (2012), Hulaifah Gaffar (2012), Rahmila Sari (2011), Siti nurhendar (2007), dalam penelitiannya menemukan bahwa pengembangan sumber daya manusia berpengaruh signifikan terhadap Laporan Keuangan yang Handal. Namun penelitian ini bertentangan dengan penelitian yuwita dan suhesti (2019).

Pengaruh tidak langsung diperoleh temuan bahwa pengembangan sumber daya manusia berpengaruh signifikan terhadap pengendalian intern dan pengendalian intern berpengaruh signifikan terhadap Laporan Keuangan yang Handal

Sehingga upaya untuk meningkatkan Laporan Keuangan yang Handal adalam menggunakan pengaruh langsung yaitu peningkatan perilaku pengembangan sumber daya manusia untuk meningkatkan perilaku perilaku Laporan Keuangan yang Handal.

Peningkatan perilaku pengembangan sumber daya manusia untuk meningkatkan perilaku Laporan Keuangan yang Handal secara kongkrit dilakukan dengan melihat skor uji validitas pengembangan sumber daya manusia terletak pada item pertanyaan tertinggi, yaitu: Terdapat pemisahan yang jelas antara garis wewenang dan tanggung jawab masing-masing fungsi dalam struktur organisasi. Pegawai ditempatkan sesuai bidang dan keahliannya. Penerimaan pegawai melalui proses seleksi.

Dengan demikian upaya ini akan berakibat pada peningkatan perilaku Laporan Keuangan yang Handal pegawai di Satuan Kerja Pemerintah Daerah Kabupaten Boyolali dalam bentuk perilaku sesuai dengan skor tertinggi dalam uji validitas Laporan Keuangan yang Handal terletak pada butir pertanyaan tertinggi menandakan bahwa butir tersebut adalah indikator yang dominan membentuk respon terhadap Laporan Keuangan yang Handal yaitu adanya peningkatan perilaku: Laporan keuangan harus disajikan secara wajar sebagai penyajian yang tulus dan wajar. Laporan keuangan harus memiliki kualitas handal dan disajikan secara wajar. Laporan keuangan merupakan alat penguji untuk menentukan atau menilai posisi keuangan perusahaan.

\section{KESIMPULAN}

a. Hasil Uji Hipotesis adalah:

1) Sistem Informasi Akuntansi berpengaruh signifikan terhadap pengendalian intern pegawai Satuan Kerja Pemerintah Daerah Kabupaten Boyolali.

2) Pengembangan sumber daya manusia berpengaruh signifikan terhadap pengendalian intern pegawai Satuan Kerja Pemerintah Daerah Kabupaten Boyolali.

3) Sistem Informasi Akuntansi berpengaruh signifikan terhadap Laporan Keuangan yang Handal pegawai Satuan Kerja Pemerintah Daerah Kabupaten Boyolali.

4) Pengembangan sumber daya manusia berpengaruh signifikan terhadap Laporan Keuangan yang Handal pegawai Satuan Kerja Pemerintah Daerah Kabupaten Boyolali.

5) Pengendalian intern berpengaruh signifikan terhadap Laporan Keuangan yang Handal pegawai Satuan Kerja Pemerintah Daerah Kabupaten Boyolali.

b. Hasil analisis jalur diketahui jalur pengembangan sumber daya manusia terhadap Laporan Keuangan yang Handal, merupakan jalur yang dominan atau efektif untuk meningkatkan Laporan Keuangan yang Handal.

\section{UCAPAN TERIMA KASIH}

Pada kesempatan ini, kami penulis mengucapkan terima kasih kepada STIE AUB Surakarta khususnya P3M STIE AUB Surakarta yang telah memberikan kesempatan dalam mengikuti penelitian hibah internal dan kami ucapkan terima kasih kepada Satuan Kerja Pemerintah Daerah Kabupaten Boyolali yang telah berkenan menjadi obyek dalam penelitian ini.

\section{REFERENSI}

Arens A, Randal J. Elder, dan Mark S. Beasley, 2012. Auditing dan Jasa Assurance Pendekatan Integritas, Jilid 2, Edisi Keduabelas, Penerbit Erlangga, Jakarta.

Amstrong, Michael.2017. Manajemen Sumber Daya Manusia, Gramedia : Jakarta 


\section{Jurnal Akuntansi dan Pajak, 21 (01), 2020, 39}

Arikunto, Suharsimi. 2016. Prosedur Penelitian. Rineka Cipta: Jakarta.

Baridwan, Zaki. 2014. Intermediate Accounting. Yogyakarta: BPFE Yogyakarta

Hartadi, Bambang, 2019, Sistem Pengendalian Dalam Hubungan dengan Manajemendan Audit. Edisi ketiga, Penerbit BPFE, Yogyakarta.

Desmiyawati. 2014. Faktor-faktor Yang Mempengaruhi Keandalan Dan Ketepatan Waktu Pelaporan Keuangan. Fakultas Ekonomi Universitas Riau, Vol.2 No.2

Djarwanto. 2011. Pokok-pokok Analisa Laporan Keuangan, Yogyakarta: BPFE.

Feriyanto. 2012. Analisis Pengendalian Intern. Penerbit BPFE, Yogyakarta

Ghozali, Imam. 2015. Aplikasi Analisis Multivariate dengan Program SPSS. Semarang: Badan Penerbit Universitas Diponegoro

Herawati, Tuti. 2014. Pengaruh Sistem Pengendalian Intern Terhadap Kualitas Laporan Keuangan. Bandung Business School, Vol XI, No.1.

Harahap, Sofyan Safri. 2012. Teori Akuntansi Laporan Keuangan. Jakarta: Bumi Aksara.

I Gusti Agung Rai. 2010. Audit Kinerja pada Sektor Publik. Jakarta : Selemba Empat.

Kiranayanti, Ida Ayu Enny. Erawati, Ni Made Adi. Pengaruh Sumber Daya Manusia, Sistem Pengendalian Intern, Pemahaman Basis Akrual
Terhadap Kualitas Laporan Keuangan Daerah. E-Jurnal Akuntansi Universitas Udayana, Vol.16.2, Tahun 2016

Mahmudi. 2017. Manajemen Kinerja Sektor Publik. Yogyakarta: UPP STIM YKPN

Mulyadi. 2011. Sistem Akuntansi. Jakarta: Salemba Empat.

Peraturan Pemerintah, 2018. Sistem Pengendalian Pemerintah. PP nomor 60 Tahun 2018

Peraturan Pemerintah, 2010. Standar Akuntansi Pemerintah. PP nomor 71 Tahun 2010

Sekaran, Uma. 2016. Metodologi Penelitian, Jakarta: Salemba Empat.

Silviana. 2014. Pengaruh Penerapan Sistem Informasi Akuntansi Terhadap Kualitas Laporan Keuangan Pemerintah Daerah. Profita, Vol 6, No 6.

Sugiyono, 2011. Metode Penelitian (Pendekatan Kuantitatif, Kualitatif, dan $R \& D)$; Alfabeta. Bandung.

YA Pravasanti, S Ningsih. 2019. Pengaruh Kualitas Aparatur Daerah, Sistem Akuntansi Keuangan Daerah, Dan Pemanfaatan Teknologi Informasi Terhadap Kualitas Laporan Keuangan Pemerintah Daerah (Studi Empiris Satuan Kerja Perangkat Daerah Kabupaten Sukoharjo). AKTSAR: Jurnal Akuntansi Syariah, Vol.2, No.2. 